p-ISSN: 2301-4261

e-ISSN: 2621-6418

EMPATI: JURNAL ILMU

KESEJAHTERAAN SOSIAL

VOL. 9 NO. 2 Desember 2020

DOI: $10.15408 /$ empati.v9i2.17897

Halaman: 108 - 115

This is an open access article under CC-BY-SA license

\section{UNBOXING A HIDDEN AGENDA OF THE WORLD'S WESTERNISATION; A NARRATIVE LITERATURE REVIEW OF THE HISTORY OF DEVELOPMENT THEORY}

\author{
M. Kholis Hamdy \\ UIN Syarif Hidayatullah, Jakarta, Indonesia \\ Email: mkholis.hamdy@uinjkt.ac.id
}

\begin{abstract}
Abstrak. To say "No" to development, by means of westernisation, in the current context may be irrelevant, especially when the definition is not proportionally set in place. Power dynamics and shifting between the North and the South or the West and The East become vivid where world polarisation is a no longer absolute measurement in socio, economic, and politics. There is no clear division on the binary. This article serves a purpose of a historical recollection of how the term development by means of westernisation by modernizing the entire world through 'development agenda setting' with long globalized westernisation efforts have a significant impact on the world's inequality. By reviewing articles narratively on the reference of development theory history, the vision of distributing equal benefits in the current world setting may not fall into similar past development agenda and development mainstreaming. Thus development ought to evolve from western origins to a global faith initiative to shape the world into non-interference, equality, and mutual benefit of sustainable development for each individual. This article concludes that the history of development theory has demonstrated the hidden agenda of the westernisation of the world since the beginning of development project, namely from the transitional period of the late nineteenth century to the beginning twentieth century. The remark of Truman is truly considered as the formal embarkation of the new era of the bold program so-called development project.
\end{abstract}

Keywords: Development; Westernisation; History; Sustainable Development.

\begin{abstract}
Abstrak. Menolak pembangunan, dalam pengertiannya westernisasi, pada konteks masa kini tidaklah relevan, khususnya ketika definisi pembangunan tidak didudukkan pada tempatnya secara proporsional. Dinamika kekuasaan dan peralihan antara Utara dan Selatan atau Barat dan Timur semakin jelas dimana polarisasi dunia tidak lagi menjadi ukuran yang absolut dalam ranah sosial, ekonomi dan politik. Tidak ada pembagian yang jelas antara dua bagian tersebut. Artikel ini bertujuan sebagai suatu penghimpunan ulang historis tentang bagaimana istilah pembangunan dalam pengertiannya westernisasi dengan memodernisasi seluruh dunia melalui 'pengaturan agenda pembangunan' dengan upaya-upaya westernisasi global yang panjang memberi dampak signifikan terhadap ketimpangan dunia. Dengan meninjau beberapa artikel secara naratif yang menjadi referensi sejarah teori pembangunan, visi untuk mendistribusikan manfaat-manfaat yang sama dalam pengaturan dunia saat ini kiranya tidak terjebak pada agenda pembangunan masa lalu yang serupa dan pengarusutamaan pembangunan. Dengan demikian pembangunan harus berubah perlahan dari asal muasal Barat-nya kepada inisiatif keyakinan global untuk menajamkan dunia menuju pembangunan yang berkelanjutan yang non-intervensi, setara, dan saling bermanfaat bagi setiap individu. Artikel ini menyimpulkan bahwa sejarah teori pembangunan telah memperlihatkan agenda terselubung dari westernisasi dunia sejak awal proyek pembangunan, yaitu dari periode transisi pada akhir abad ke-19 hingga awal abad ke-20. Kesimpulan Truman sangat dipertimbangkan sebagai embarkasi formal era baru program yang disebut proyek pembangunan.
\end{abstract}

Kata Kunci: Pembangunan; Westernisasi; Sejarah; Pembangunan Berkelanjutan.
Open Journal Systems Read Online PDF Reader 


\section{INTRODUCTION}

The word development, in terms of its use, has been and will always be undeniably common in the public sphere, especially in the political domain; local, national, regional, and international stages. It is not worth to differentiate the various definitions based on the enormous resources available. However, for the sake of this article, there is an urgency to base a common ground of basic understanding of the term. Therefore, a historical approach will serve as not only for the definition per se but also a mean of discussing or in a way, demonstrate how the notion of development is merely a concept of westernisation (modernization) that was purposely designed to economically drive ideas prescribed as the means to the universal improvement of humankind.

The term has been comprehended through various perspectives such as from biological metaphor, historical ideas, economy, social and even religious dogma. Biological perspective argues, strongly influenced by ancient Greek thinking, that the term, which means of growth and maturation, is the process of reaching potential for example from seed to become a tree; the notion of undeveloped to fully developed stage. The assumption is that every species has a distinct nature in fulfilling their potentialities and if they fail to do so, then mistakes may have taken place, intervening the natural force to progress, reach one certain direction and fulfilling necessary cumulative stages (Esteva, 1992). Therefore, in this regard, the common message is that development is an upright notion and it simply is a process of movement from a worse state to a better state.

In western thinking of history, a story of progress (from worse to better) has dominantly prevailed excluding other conception such as degeneration and cyclical, thus it embeds a linear historical consciousness which relates to an increase in human powers in terms of rationality, knowledge and their relation to nature. St Augustine argued, as referred to Sach (1992), that humanity has a universal history that human stages of history starting from infancy to old and human events are both merely fulfilling human progress to develop. This increasing of human powers, for example, the rationality, is regarded as humanity's growing maturity that was articulately defined by August Comte with his three stages; theological, metaphysics and science; Karl Marx with the evolving notion of feudalism and primitive modes of production, and Herbert Spencer with the evolutionary approach of development in terms of rationality and individualism. Thus, the west has been strongly perceived as the culmination of highest states of human or humanity development or even 'peak civilisation of mankind' and these thoughts have reached dominancy and status quo of the 'one world' by progress stimulation everywhere and the realization of 'unity of the world' through westernisation (Sach, 1992).

\section{METHOD}

This framework reflects on responsibility senses of civilising the natives in line with brutal power relations existed since the period of colonialization which marked the start of the great adventure 1870-1940, as a transitional period on which opened the way to development (Rist, 2014). The question is whether the current state of what so-called development has been nothing more than a westernisation by modernizing the entire world through 'development agenda setting' with long globalized westernisation efforts. This essay is an attempt to discuss the question. This essay is qualitative by mostly referencing two main preferences; namely a book of Gilbert Rist (2014), The History of Development: From Western Origins to Global Faith, and using Wolfgang Sach's (1992) 
deconstructive description on development as "stand like a ruin in intellectual landscape" in examining the westernisation (modernisation) regarding the notion of development through a historical perspective. Historical means here is not through an excessive use of a heuristic approach by examining the whole grand narrative of texts. However, earlier great text such as Truman's Speech will serve as an argumentation basis to what extent the idea of development inherently embeds the hidden agenda of westernisation/ modernisation.

\section{RESULTS AND DISCUSSIONS}

To foster a broader understanding of the definition of the West, Western, or Westernisation, several prominent authors have described them in various aspects. Huntington (1993) categorises 'western' based on a religious association basis; reasoning western Christian part of Europe and North America as the West, while other 6 civilizations consist of Confucian, Latin America, Islamic, Japanese, Hindu and Slavic-Orthodox, as the East. Huntington further claims that after the end of the cold war, world politics would move into a new aspect in which non- Western civilizations were no more the exploited recipients of Western civilization but become another important actor joining the West to shape and move the world history. Although Sen (2001), as referred by Scholte (2008), has not explicitly indicated the similarity between globalization and westernisation, there are several highlighted parallel issues relating to the effect of westernisation in a way such as inequalities and fairer distribution of both North and South. Sach (1992), using UN Declaration as a background, describes that by achieving one world or so-called unity of the world which inevitably calls for absorbing differences of the world into an ahistorical and delocalised universalism of
European origin is a simple means of westernisation of the underdeveloped replacing the savages terminology. Oxford Dictionary Online (http://www.oxforddictionaries.com/) defines westernisation with the word westernise (with object) which means as a cause (a country, person, or system) to adopt or be influenced by the cultural, economic, or political systems of Europe and North America. Thus, westernizing the underdeveloped here means through modernisation based on western orientation.

In the book of Development Dictionary: A Guide to Knowledge as Power, development has been analysed with the under-development, environment approach as a justification for sustained (not sustainable) development, a Christian virtue development (philanthropic), and as a rising political participation slogan. Progress has been considered as a belief that 'toothpaste' (western science) is the answer to primitive technology while the production concept is portrayed by the story of Don Bartolo's cornfield (Kolås, 1994). The philanthropic synthesis of the development could be traced back to Victor Hugo Commemoration, as quoted by Rist (2014), that the "white made a man of black... to fashion a new Africa, to make old Africa amenable for civilization... take it, not for the saber but commerce! not for battle but the industry! not for conquest but fraternity!" Strong base for the other version of development post-WWII was partly influenced by that extraordinary synthesis; holding a global premise of civilisation for humankind and that is an expression of solidarity growth, sense of community, and vested interest which entangles the metropolis to its overseas possession (Rist, 2014).

1945 is a key year of reification in which development as an agenda-setting marked by the establishment of the World Bank and Bretton Woods institutions 
(Kothari, 2019). In search of the hidden agenda of development as merely a westernisation as Sach argued, it is necessary to discuss important events considered crucial, especially Truman's speech. Post WWII, there was a need for America to expand the international market, in this case, is Western Europe, due to altering the wartime industry into peace production and dealing with communism concern if Europe did not rebuild in a fast manner. Thus, the Marshal Plan was introduced; bringing extensive US aid with the dismantling trade barriers.

The real kick-off of the development project was strongly considered with Truman's inaugural speech in 1948 by mentioning 4 of US commitment namely: 1 . US will be a UN member, 2. Marshall Plan is deemed for implementation, 3. the creation of NATO, and 4. US leadership in development projects globally (Rist, 2014). The address contains several dichotomous key terms that shaped the framework of development project especially Truman's point four such as introducing the word 'underdeveloped' and explicit power relation of 'North-South' stated that "Fourth, we must embark on a bold new program for making the benefits of our scientific advances and industrial progress available for the improvement and growth of underdeveloped areas" (Truman, 1949).

The speech exclaimed one linear development process for the rest of the world; those that have fallen behind must catch up under the US lead. In this sense, there is a legitimate measure for intervening the poor, through globalization, westernising or modernising through economic liberation, namely in the South. Thus, there have been several impacts from the rise of globalised world under neoliberalism as the prominent practice, namely, a large scale and scope of economic growth (market expansion); transforming nature into commodities, secondly, this open market, in consequence, has forced the East and the South to accelerate natural treasure exploitation to pay foreign debts and to achieve currency stabilities, for example, Senegal sells fishing rights to Japan and Spain while Brazil, Indonesia and Mexico facilitated forest exploitation and thirdly, pressuring governments to deregulate public goods protection for commercial interest (Sach, et. 2002). This economic liberation, given colonial acquisitions of Louis-Phillippe and Napoleon III, observed by many prominent scholars such as Montesquieu, Rousseau and Adam Smith, as Rist mentioned, was much more advantageous than a commercial monopoly. Because it created a large market and allowed the industry to develop both in the metropolis and overseas (Rist, 2014).

Parajuli (1996) states that, based on the review of a well-known piece of critics work of development, there is a rarely exist an effort to criticise the status quo in terms of the history of development thinking; striking at its heart by mentioning it as an obituary of development and pursuing further than as archeology of development as well as searching possible alternative measure to development. There are at least five premises that have been argued in this book. The first, development is merely a means of inventing underdevelopment as a project and therefore claiming 2 billion people into the category; inserting forcefully one's value into others; and labelling the majority to become homogenized. Consequently, they become a manageable enterprise through what so-called strategy, planning, monitoring and evaluation discourses (knowledge as power). The statement deliberately mentioned that half of the world population lives in near misery condition; inadequate of food, vulnerable to disease, primitive and stagnant economy in addition to the strong address on the poverty of the underdeveloped as two-way threats; both North and South (Truman, 1949).

Secondly, the book is a demythicisation of development by apting other plausible 
terminologies such as ethno development participatory development, sustainable development and the innocence of the developmental state although it is argued that there is no possibility to 'sweeten' the bitter pill of development. Thus, development has intrinsically given no place for dialogue, participatory, and empowerment to the underdeveloped nations (people) (knowledge as power). The above argument is probably based on the appearance of the underdevelopment term that evoked not only to achieve a final state of direction but also it is possible to bring about such a state (development). The development embeds transitive meaning that implies an action performed by one agent to another; corresponding to social organization principles, while at the same time, underdevelopment was a natural occurrence; state of thing. This meaning can be identified by the speech "...to help them realize their aspirations for a better life. And, in cooperation with other nations, we should foster capital investment in areas needing development," (Truman, 1949, p.48).

Thirdly, the premise contains Marx's variant such as social intervention and critically pedagogical elements inspired by both Gramsci and Freire. This socialist alternative measurement gives alternative forms of development by putting empowerment for general classes; emphasizing development as the process of a history that will unfold natural laws characters' necessity and elevate the consciousness of intellectual or activists. However, these socialism argumentation values are not considered as replacement entities of the existing regime but rather as a metanarrative and subordinate diversities. Interestingly, it seems that the reluctant use of socialism is in line with strong opposition in Truman's address in the notion of democracy versus communism (Truman, 1949).
The fourth argument is that development destroys both culture and natural ways addressing human's backwardness to nature management. Therefore, there is a need for cultural transformation in terms of skilled human resources. Besides, this value is intended to criticise the terminology of sustainable development; as mentioned in Brundtland Commission, that not focusing on the survival of humans but still emphasising the nature exploitation; excluding the limitation of nature's capacity for abuse under the flag of development. Excessive aid, debt relief and market opening of export from the poor are equal to lead down the business as usual; industrial development; craving for exhausted Earth's resources (Gardels, 2002). Thus, this version of the development is merely a mean to ensure industrial production need for a continued supply of raw materials' more flow and indefinite accumulation of capital. (Sach, 1992). Besides, the fact prevails, in terms of environment, that sustainability is possibly compatible with development in the notion of political domain, but not in the scope of natural limits. The majority of the poor may detest or envy the rich but replicating lifestyle of theirs will likely be ecocide (Gardels, 2002).

Putting Truman's address into the examination, there are several key points, which may be already mentioned above, among them are a) the term of underdeveloped and the necessity for improvement and growth; b) claiming a position as the higher class by pointing half of the Earth's population under miserable conditions in terms of well-being and economy (poverty); c) the emphasise on the science to relieve the suffering; $d$. the address on the raw materials and the assumed of need for assistances from America; e. a call for international cooperation of nations to foster capital investment, a worldwide effort to achieve 
peace, plenty, and freedom; f. the important cooperation among business, private capital, agriculture and labor inside America that will contribute industrial activity in other nations and raise living standards substantially; g. a devised and controlled new economic development; $h$. strong rejection of old imperialism; i. better use of human and natural resources; j. prosperity and peace based on greater production, science and technical knowledge; and k. reaffirmation of democracy position (Truman, 1949).

According to Rist (2014), shreds of evidence show that the use of the development word for example in a socioeconomic context rather than underdeveloped which was first use in a wide circulated text and has a synonym meaning for economically backward areas such as prominent scholars like Marx, LeroyBeaulieu, Schumpeter, Rosenstein, Roden, etc. Both uses of the term has radically shaped the world view from the North-South that was largely organised in the notion of confrontation colonised/colonizer. Both have a tendency of a subordinate hierarchical position of metropolis/colony with every state has equal de jure though it may not be de facto. Developed and underdeveloped terms become one entity; one family, one might be left behind to the other but it is possible to catch up. Thus, one is not the opposite of the other, only that it is incomplete.

In the fortieth IDS Conference, Sach (2007) described that the rise and success of the European, by giving one example of Britain that has limited resources, was primarily due to two factors; carbon and colonies, and coal exploitation of industrial determinations from the crust of the earth. While colonialisation highly contributed to an extensive amount of agricultural products from the land of colonies such as from the Caribbean and north-east of Brazil in addition to Britain leisure access to timber, sugar, tobacco and many other products.
Thus, in other words, carbon and colonies are two folds in one coin in shaping today's industrial societies that had no resources exploited from both the expense of geological and the abuse of geographical space.

The two were perquisites circumstances that rose up the special case of Euro-Atlantic civilization (Sach, 2007). In pursue of justice in the world, concealed within development discourse may be attained through contraction and convergence; using the environmental approach, a transitional call for a different forms of prosperity such as a sustainable and resource-light is needed. The retreat of North's excessive use of environmental space; contraction of resource consumption contraction must take place by reducing 80 to 90 per cent of fossil use, such as the policy to weight a lightly approach on mother earth. Secondly, although it is a sound mimic, developing countries have to be given the space to flourish their development within an appropriate measure, bearing in mind not to reach the same trajectory taken by the North countries (Sach, 2007).

This approach eventually will possibly reposition both situation into a more justice balance (Sach, 2007). The need to move beyond North and South orientation of international development has been acknowledged by Horner (2017) due to longstanding critiques of the North-South binary, global interconnectedness, the universal relevance of sustainability, and the contemporary blurring of the North-South boundary, with the discussion global development terminologies, and proposes a term of global development. Currie-Alder (2016), argues that development, as a study, should build dialogues on sovereign challenges concerning the national wealth use, global interdependencies and foreign obstacles on how to respond to troubled places across the globe. Development discourse ought to serve as the meeting place of contraction and convergence that connect, critique and to shape the world into non- 
interference, equality, and mutual benefit of sustainable development.

\section{CONCLUSION}

The history of development has demonstrated the hidden agenda of the westernisation of the world since the beginning of the development project, namely from the transitional period of the late nineteenth century to the beginning twentieth century. The remark of Truman was truly considered as the formal embarkation of the new era of the bold program so-called development project. Although, the inaugural address seemed nothing out of ordinary good intention, it strongly lacks of expectations and strong commitments. The addressing was merely talks on mobilizing nonmaterial resources (science and technology), North American stakeholders, namely capitalists, farmers and workers, and of course international community.

The process of development from the beginning, based on historical events and sequences of discourse in the western sphere, had strongly influenced by the western regime of knowledge from historical approach, evolutionism, economy, philanthropy, and politically. Thus, in the simplest way of saying, any effort to put one's position into others attributed values is extremely crucial in the idea of development. The history notes the development agenda to elevate the half underdeveloped people of the world is by following the exact footsteps of the civilized, unfortunately, a past bitter pill.

\section{REFERENCES}

Esteva, G. (1992). Development. In Sach, W. (Ed.), The Development Dictionary: $A$ Guide to Knowledge as Power (pp. 625). London; New Jersey: Zed Press.
Gardels, N. (2002). De-Industrializing desire. New Perspectives Quarterly, 19(3), 25.

doi:10.1111/j.1540-5842.2002.tb00080.x

Huntington, S. P. (1993). The clash of civilizations?. New York: Council on Foreign Relations.

Horner, $\mathrm{R}$ (2017). What is global development? GDI Working Paper 2017-020. Manchester: The University of Manchester.

Kothari, U. (Ed.). (2019). A radical history of development studies: Individuals, institutions and ideologies. Zed Books Ltd.

Kolås, Å. (1994). Review of the Book. The Development Dictionary: A Guide to Knowledge as Power. Journal of Peace Research, Vol. 31, No. 1 (Feb), pp. 122.

Parajuli, P. (1996). Review of the Book. The Development Dictionary: A Guide to Knowledge as Power. American Ethnologist. Vol. 23, No. 3 (Aug), pp. 641-642

Rist, G. (2014). The History of Development; From Western Origin to Global Faith. London: Zed Books.

Sachs, W. (1992). The Development Dictionary: A Guide to Knowledge as Power. London; New Jersey: Zed Press.

Sachs, W., Acselrad, H., Akhter, F., Amon, A., Egziabher, T. B. G., French, H. \& Agrawal, $\mathrm{H}$.

(2002). Fairness in a fragile world: A memo on sustainable development. New Perspectives Quarterly, 19(3), 8-42. doi:10.1111/j.1540-

5842.2002.tb00082.x

Sachs, W. (2007), Global Challenges: Climate Chaos and the Future of Development. IDS

Bulletin, 38: 36-39. doi: 10.1111/j.17595436.2007.tb00348.x

Scholte, J. A. (2008). Defining Globalisation. World Economy, 31(11), 1471-1502.

doi:10.1111/j.1467-9701.2007.01019.x 
Sen, A. (2001). Ten theses on globalization. New Perspectives Quarterly, 18(4), 915. doi:10.1111/0893-7850.00430

Truman, H. (1949). Inaugural Address. Retrieved from Inaugural Senate on May 2nd $2020 \quad$ from http://www.inaugural.senate.gov/swe aring-in/event/harry-s-truman-1949 